\title{
REALITA TRANSFORMASI DIGITAL PENDIDIKAN DI SEKOLAH DASAR SELAMA PANDEMI COVID-19
}

\author{
Ricka Tesi Muskania ${ }^{1}$, Zulela MS ${ }^{2}$ \\ Email: ricka.muskania@gmail.com ${ }^{1}$, zulela@yahoo.com² \\ PGMI, FTIK, Institut Agama Islam Negeri Pontianak ${ }^{1}$ \\ Pendidikan Dasar, Pascasarjana, Universitas Negeri Jakarta ${ }^{2}$
}

\begin{abstract}
Abstrak: Pendidikan merupakan usaha sadar yang dilakukan untuk memberikan pengalaman belajar bagi peserta didik. Pengalaman ini terdiri dari aspek kognitif, afektif, dan psikomotor. Penelitian ini dilatarbelakangi oleh keadaan pendidikan di sekolah dasar pada masa pandemi covid-19. Dalam keadaan darurat covid-19, pemerintah mengeluarkan kebijakan tentang pembelajaran jarak jauh dan daring agar peserta didik dapat belajar walaupun dalam keadaan social distancing. Tranformasi digital guru dan peserta didik merupakan dampak dari proses pembelajaran selama covid-19. Penelitian ini merupakan penelitian kualitatif dengan jenis studi kasus. Sumber data adalah guru dan peserta didik di SD/MI yang dipilih secara purposive sampling. Teknik yang digunakan adalah teknik wawancara dan observasi dengan instrumen lembar wawancara dan catatan lapangan terhadap realita pelaksanaan pendidikan di sekolah. Hasil penelitian menunjukkan bahwa $80,8 \%$ proses pembelajaran yang berlangsung bagi peserta didik kelas rendah sepenuhnya dikendalikan oleh orang tua, sedangkan pada kelas tinggi proses pembelajaran secara daring dan jarak jauh tidak seperti pembelajaran formal yang seharusnya. Hasil penelitian ini memberikan gambaran bahwa realita pendidikan dasar di Indonesia belum siap dari segi sumber daya manusia, dan teknologi khususnya pada daerah 3T.
\end{abstract}

Kata kunci: Tranformasi digital, literasi ICT, sekolah dasar, covid-19.

\section{THE REALITY OF EDUCATION DIGITAL TRANSFORMATION IN BASIC SCHOOLS DURING THE COVID-19 PANDEMIC}

\begin{abstract}
Education is a conscious effort made to provide learning experiences for students. This experience consists of cognitive, affective, and psychomotor aspects. This research is motivated by the state of education in primary schools during the Covid-19 pandemic. In the state of the Covid-19 emergency, the government issued a policy on distance and online learning so that students can learn even in social distancing conditions. The digital transformation of teachers and students is the impact of the learning process during Covid-19. This research is a qualitative research with a type of case study. The data sources were the teachers and students in SD/MI which were selected by purposive sampling. The techniques used are interview and observation techniques with interview sheet instruments and field notes on the reality of the implementation of education in schools. The results showed that $80.8 \%$ of the learning process that took place for low-grade students was completely controlled by their parents, while in high-grade students the online and distance learning process was not as formal as it should be. The results of this study illustrate that the reality of basic
\end{abstract}


Kukuh, Rian, Bagus. Empat Kata Judul Dari Depan...

education in Indonesia is not yet ready in terms of human resources and technology, especially in $3 \mathrm{~T}$ areas.

Keywords: Digital transformation, ICT Literacy, elementary school, covid-19.

\section{PENDAHULUAN}

Penelitian ini dilakukan dengan dilatarbelakangi oleh situasi saat ini di Indonesia yang sedang melakukan social distancing sehingga semua sekolah dasar dan madrasah ibtidaiyah dilaksanakan secara jarak jauh, dalam jaringan (daring), dan luar jaringan (luring) seperti yang dilakukan oleh negara lainnya yang terdampak corona (Carrillo \& Flores, 2020; Donitsa-Schmidt \& Ramot, 2020). Pelaksanaan pembelajaran ini mengacu pada surat edaran yang dikeluarkan oleh Kementerian Pendidikan dan Kebudayaan tentang pelaksanaan pembelajaran selama masa darurat covid-19. Pembelajaran jarak jauh dapat dilaksanakan dengan berbagai aplikasi pendukung, begitu pula dengan pembelajaran daring. Sedangkan pembelajaran luring dilaksanakan melalui stasiun televisi di TVRI yang programnya telah dirancang dengan bekerja sama dengan kemdikbud.

Penelitian ini dilaksanakan dengan tujuan untuk mendeskripsikan realita pelaksanaan pembelajaran pada jenjang sekolah dasar baik yang ada di perkotaan maupun di daerah tertinggal. Pelaksanaan pembelajaran selama masa pandemi covid-19 memberikan dampak positif dan negatif. Salah satu dampak positif dari pembelajaran secara daring atau jarak jauh adalah memicu percepatan transformasi pendidikan, pembelajaran yang lebi fleksibel dimanapun dan kapanpun, sedangkan dampak negatifnya belum siapnya SDM dan Perangkat ketika menerapkan pembelajaran jarak jauh (Widakdo \& Fananie, 2020). Pada keadaan darurat pandemi Covid-19 problematika yang ditampilkan akan semakin bertambah, tidak hanya pada daerah 3T tetapi juga di daerah perkotaan. Selama pandemi Covid-19 semua proses pembelajaran dialihkan ke pembelajaran dalam jaringan (daring) apalagi untuk daerah dengan zona merah. Pembelajaran dilaksanakan dengan berbagai aplikasi yang dapat digunakan selama pembelajaran daring.

Pengaruh covid-19 memberikan dampak pada transformasi teknologi pada pendidikan di Indonesia khususnya jenjang sekolah dasar. Teknologi informasi adalah kata kunci dalam pembelajaran daring ataupun jarak jauh selama pandemi covid-19 agar 
Kukuh, Rian, Bagus. Empat Kata Judul Dari Depan... memungkinkan peserta didik belajar lebih baik, lebih cepat, dan lebih pintar (Pujilestari, 2020). Istilah lain dikenal dengan ICT (Information and Communication Technology). UNESCO mengungkapkan bawa ada beberapa manfaat yang dapat diperoleh dengan menerapkan ICT dalam sistem pendidikan yaitu mempermudah dan memperluas akses jejaring pendidikan, meningkatnya kesetaraan pendidikan, mutu pembelajaran, profesionalisme guru serta lebih efektif dan efisien dalam manajemen dan tata kelola pendidikan(Adisel, Gawdy, 2020). Orang yang melek digital dan teknologi informasi dapat dikatakan memiliki ICT literacy yang memadai (Tesi Muskania \& Wilujeng, 2017). Guru dalam praktek pelaksanaan pembelajaran daring dan jarak jauh juga harus memiliki ICT literacy yang memadai agar memudahkan proses pembelajaran sehingga guru memerlukan pelatihan khusus untuk meningkatkan kompetensi ICTnya (König et al., 2020).

Penelitian ini bertujuan untuk mendeskripsikan problematika yang dialami guru dan peserta didik selama masa pandemi covid-19 yang menyebabkan transformasi digital pada dunia pendidikan khususnya pendidikan dasar di Indonesia. Beberapa penelitian yang relevan dengan penelitian ini adalah penelitian dengan judul dampak Covid-19 terhadap Implementasi Pembelajaran Daring di Sekolah Dasar dengan hasil penelitian bahwa proses pembelajaran secara daring dapat menggunakan berbagai aplikasi pendukung, sedangkan pembelajaran di kelas rendah memerlukan kerjasama antara orang tau dan guru karena anak belum mahir mengaopersikan perangkat dan aplikasi yang digunakan dalam proses pembelajaran (Dewi, 2020). Penelitian kedua dengan judul Dampak Covid-19 Terhadap Dinamika Pembelajaran di Indonesia, hasil penelitian yang diperoleh adalah dampak Covid pada pendidikan di Indonesia adalah 1) sekolah dialihkan ke rumah melalui proses pembelajaran daring; 2) terjadi transformasi media pembelajaran berbasis teknologi melalui penggunaan Wathshap Group, Zoom, Google Classroom, WebEx, Youtube, dan saluran TV (TVRI); 3) penyesuaian metode pembelajaran; 4) penyesuaian evaluasi pembelajaran untuk penentuan standar kenaikan kelas dan kelulusan; dan 5) tuntutan kolaborasi orangtua peserta didik di rumah sebagai pengganti guru mengontro pembelajaran anak (Mansyur, 2020). Penelitian ketiga dengan judul Kendala Pembelajaran Daring Guru Sekolah Dasar di Kabupaten Banjarnegara, hasil penelitiannya kendala yang dialami guru selama pembelajaran 
Kukuh, Rian, Bagus. Empat Kata Judul Dari Depan...

daring yaitu aplikasi pembelajaran, jaringan internet dan gawai, pengelolaan pembelajaran, penilaian, dan pengawasan (Rigianti, 2020).

\section{METODE}

Penelitian ini merupakan penelitian kualitatif dengan penelitian studi kasus yang menjadikan guru dan peserta didik sebagai subjek penelitian. Sumber data berasal dari guru dan peserta didik yang melaksanakan pembelajaran selama masa pandemi di berbagai kota dan kabupaten yang ada di provinsi Kalimantan Barat. Sampel ditentukan secara purposive sampling dengan jumlah 4 orang guru dan 4 orang peserta didik sebagai perwakilan dari kabupaten dan kota. Teknik yang digunakan untuk mengumpulkan data adalah teknik wawancara mendalam dengan instrumen lembar wawancara tentang pelaksanaan pembelajaran di sekolah dasar. Analisis data dilakukan dengan reduksi data, pengelolaan dan pengelompokkan data, intepretasi, dan penarikan kesimpulan.

\section{HASIL}

Proses pembelajaran yang berlangsung di Indonesia jika dilihat dari lokasi sekolah, maka dapat dikelompokkan dalam sekolah yang ada di perkotaan dan yang ada di daerah. Secara umum, sebelum pandemi covid proses pembelajaran yang berlangsung ditinjau dari beberapa aspek ditampilkan pada Tabel 1.

Tabel 1. Proses Pembelajaran Sebelum Pandemi Covid-19 di Indonesia

\begin{tabular}{|c|c|c|c|}
\hline \multirow{2}{*}{ No } & \multirow{2}{*}{ Aspek } & \multicolumn{2}{|c|}{ Daerah } \\
\hline & & Kota & $3 \mathrm{~T}$ \\
\hline 1 & Sarana Prasarana & $\begin{array}{l}\text { Sebagian besar sarana } \\
\text { dan prasarana } \\
\text { pembelajaran menunjang, } \\
\text { bahkan sangat menunjang } \\
\text { dalam proses } \\
\text { pembelajaran }\end{array}$ & $\begin{array}{l}\text { Sebagian besar sarana dan } \\
\text { prasarana pembelajaran tidak } \\
\text { menunjang proses } \\
\text { pembelajaran, ini terlihat dari } \\
\text { kondisi bangunan dan keadaan } \\
\text { kelas yang sangat tidak layak } \\
\text { untuk digunakan dalam proses } \\
\text { pembelajaran. }\end{array}$ \\
\hline 2 & Lingkungan & $\begin{array}{lr}\text { Lingkungan } & \text { perkotaan } \\
\text { mendukung } & \text { adanya } \\
\text { proses } & \text { pembelajaran } \\
\text { karena } & \text { peserta didik }\end{array}$ & $\begin{array}{l}\text { Pada daerah } 3 \mathrm{~T} \text {, lingkungan } \\
\text { tidak bersahabat pada proses } \\
\text { pembelajaran, contohnya } \\
\text { Anak harus menempuh }\end{array}$ \\
\hline
\end{tabular}


Kukuh, Rian, Bagus. Empat Kata Judul Dari Depan...

\begin{tabular}{|c|c|c|c|}
\hline \multirow{2}{*}{ No } & \multirow{2}{*}{ Aspek } & \multicolumn{2}{|c|}{ Daerah } \\
\hline & & Kota & $3 T$ \\
\hline & & $\begin{array}{l}\text { secara umum akses untuk } \\
\text { ke sekolah lebih mudah } \\
\text { dan tidak ada tuntutan } \\
\text { orang tua untuk bekerja } \\
\text { kepada anaknya. }\end{array}$ & $\begin{array}{l}\text { jarak berkilometer dengan } \\
\text { berjalan kaki untuk ke } \\
\text { sekolah. } \\
\text { 2) Medan yang dilalui } \\
\text { untuk ke sekolah bukan jalan } \\
\text { yang mulus, tetapi mereka } \\
\text { harus melalui sungai, tanah } \\
\text { yang berlumpur, jembatan } \\
\text { yang rusak. } \\
\text { 3) Belum lagi tuntutan } \\
\text { orangtua untuk membantu } \\
\text { bekerja seperti berladang, } \\
\text { berkebun, dan lain-lain. }\end{array}$ \\
\hline 3 & Sumber Belajar & 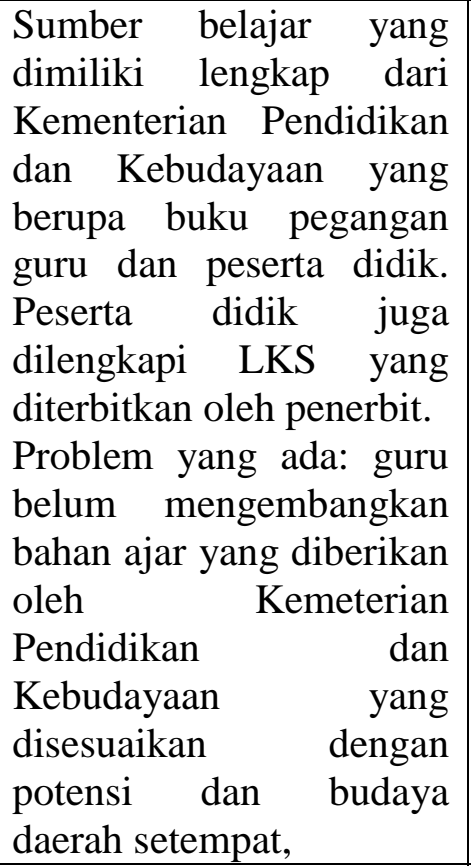 & $\begin{array}{l}\text { Sumber belajar yang terbatas, } \\
\text { bukuk pegangan guru dan } \\
\text { peserta didik jumlahnya } \\
\text { terbatas sehingga harus } \\
\text { dipegang oleh guru, dan } \\
\text { digunakan secara } \\
\text { berkelompok di kelas. Peserta } \\
\text { didik juga tidak memiliki } \\
\text { buku pegangan yang dapat } \\
\text { dibawa pulang. }\end{array}$ \\
\hline 4 & Media Pembelajaran & $\begin{array}{l}\text { Media pembelajaran } \\
\text { menerapkan penggunaan } \\
\text { multimedia dari cetak, } \\
\text { audio, video animasi, dan } \\
\text { sebagainya. }\end{array}$ & $\begin{array}{l}\text { Guru jarang menggunakan } \\
\text { media. Media yang sering } \\
\text { digunakan adalah media cetak } \\
\text { atau media yang langsung } \\
\text { berasal dari lingkungan } \\
\text { sekitar. }\end{array}$ \\
\hline 5 & Jam belajar & $\begin{array}{l}\text { Pukul } 07.00-15.00 \text { wib } \\
\text { (fullday) }\end{array}$ & $\begin{array}{l}\text { Pukul } 09.00-11.00 \text { wib } \\
\text { Bahkan ketika peserta didik } \\
\text { kelas tinggi izin pulang karena } \\
\text { adiknya dikelas rendah sudah } \\
\text { pulang, peserta didik yang } \\
\text { bersangkutan diizinkan } \\
\text { pulang. Dan ini akan } \\
\text { berlangsung setiap hari. }\end{array}$ \\
\hline
\end{tabular}


Kukuh, Rian, Bagus. Empat Kata Judul Dari Depan...

\begin{tabular}{|c|c|c|c|}
\hline \multirow{2}{*}{ No } & \multirow{2}{*}{ Aspek } & \multicolumn{2}{|c|}{ Daerah } \\
\hline & & Kota & $3 T$ \\
\hline 6 & ICT & $\begin{array}{l}\text { Secara umum } \\
\text { kemampuan ICT } \\
\text { memadai ditinjau dari sisi } \\
\text { guru dan peserta didik, } \\
\text { kecuali untuk guru-guru } \\
\text { yang sudah sepuh. }\end{array}$ & $\begin{array}{l}\text { Penggunaan ICT di daerah } 3 \mathrm{~T} \\
\text { sangat minim, karena di } \\
\text { daerah } 3 \mathrm{~T} \text { bahkan listrik } \\
\text { hanya ada di malam hari. }\end{array}$ \\
\hline
\end{tabular}

Pembelajaran daring mengharuskan guru melek teknologi karena tanpa ICT literacy yang baik maka guru akan sulit untuk membuat proses pembelajaran menjadi bermakna. Oleh karena itu kemampuan literasi digital mutlak dibutuhkan dimasa pandemi (Nahdi \& Jatisunda, 2020). Belum lagi keterbatasan perangkat yang dimiliki oleh peserta didik karena tidak semua berasal dari keluarga dengan ekonomi menengah keatas yang minimal memiliki android sebagai perangkat penunjang proses pembelajaran. Hal inilah yang menjadi temuan peneliti dengan beberapa masalah dalam proses pembelajaran di Sekolah Dasar pada daerah perkotaan.

Berdasarkan hasil wawancara pada daerah 3T masalah akan semakin bertambah masalah yang dihadapi oleh guru dan peserta didik dalam proses pembelajarannya, yaitu:

a. Listrik yang terbatas (ada beberapa daerah yang memiliki akses listrik hanya di malam hari).

b. Perangkat penunjang pembelajaran yang sangat terbatas

c. Keterampilan penggunaan teknologi yang terbatas bagi anak-anak karena tidak pernah menggunakan perangkat teknologi seperti android, laptop, dan sebagainya.

d. Terbatasnya sinyal, karena dibeberapa daerah sulit sinyal bahkan tidak memiliki sinyal sama sekali. Jika adapun mereka harus ke daerah yang lebih tinggi dengan medan tempuh yang tidak semulus daerah perkotaan dengan jarak berkilometer. Mungkin mereka harus memanjat pohon atau naik ke atas gunung atau bukit.

Kendala lain yang muncul dalam proses pembelajaran daring dimana semua pendidikan dilaksanakan dalam upaya pembentukan kepribadian. Pendidikan pada jenjang Sekolah Dasar merupakan pendidikan formal yang memberikan nilai dan norma 
Kukuh, Rian, Bagus. Empat Kata Judul Dari Depan...

dasar dalam membentuk kepribadian seorang anak agar dapat menjadi manusia yang seutuhnya dimasa dewasa nanti. Pelaksanaan pembelajaran daring yang berbasis teknologi memberikan dampak negatif yaitu terhadap degranasi moral dan kepribadian peserta didik. dalam kondisi yang formal seperti proses belajar mengajar, kondisi yang dialami tidak formal yang dapat dilihat dari cara berpakaian peserta didik, suasana sekitar peserta didik bahkan ada beberapa peserta didik yang digantikan oleh orangtuanya hingga dalam pengerjaan soal latihan dan ujian akhir. Hal ini akan sangat berdampak dalam pembentukan karakter generasi penerus bangsa. Karena segala sesuatu mungkin dapat digantikan oleh teknologi tetapi ada satu hal yang tidak dapat digantikan oleh teknolgi yaitu pembentukan karakter dan kepribadian peserta didik yang memerlukan perhatian ekstra yang bersifat berkelanjutan dan pemodelan.

\section{PEMBAHASAN}

Pembelajaran selama masa covid-19 memberikan dampak yang sangat signifikan terutama pada penggunaan teknologi dalam proses pembelajaran. Pembelajaran yang berlangsung menuntut kemampuan penggunaan teknologi dalam pelaksanaannya (Nahdi \& Jatisunda, 2020). Ketergantungan masyarakat terhadap internet menjadikan digitalisasi pendidikan sebagai satu-satunya cara yang dapat dilakukan selama masa pandemi covid-19 (Gumelar \& Dinnur, 2020). Permasalahan ini akan semakin sulit bagi daerah 3T (terdepan, terluar dan tertinggal) karena sebelum pembelajaran daring pun sudah banyak permasalahan di daerah 3T ini (Putra et al., 2019), mulai dari tidak tersedianya listrik hingga tidak terdapatnya sinyal di daerahnya sehingga pelaksanaan pembelajaran yang sesuai dengan surat edaran No 4 tahun 2020 tentang pelaksanaan pembelajaran dilaksanakan secara daring tanpa kontak dan pertemuan antara guru dan murid yang dikeluarkan oleh Kementerian Pendidikan dan Kebudayaan (Putro et al., 2020) tidak dapat terlaksana sepenuhnya di daerah $3 \mathrm{~T}$ karena keterbatasan tersebut. Solusi yang dapat diberikan dalam proses pembelajaran daring di daerah $3 \mathrm{~T}$ adalah melaksanakan pembelajaran dari rumah (School from Home) dengan pendekatan home visit atau dikenal dengan istilah GULING (Guru Keliling). Istilah ini muncul selama masa pandemi covid-19 dimana guru berkeliling melayani peserta didik yang tidak dapat mengakses kegiatan belajar mengajar secara online (Gumelar \& Dinnur, 2020). Pendekatan ini berorientasi pada pelaksanaan pembelajaran dari rumah kerumah dengan 
Kukuh, Rian, Bagus. Empat Kata Judul Dari Depan... tetap menggunakan seragam sekolah seperti biasa. Hanya saja, suasana belajar akan berbeda dengan kondisi sebelumnya karena pendekatan home visit (Syibromilisi, 2020) seperti les private. Sebagai penyeimbang kegiatan pembelajaran dan penyetaraan kemampuan digital guru yang mengajar di daerah 3T diperlukan pelatihan khusus inovasi pembelajaran karena walau dalam keterbatasan inovasi guru-guru harus tetap perlu dikembangkan (Putro et al., 2020; Suprihatiningsih \& Sudibyo, 2020).

Pada daerah perkotaan diperlukan pelatihan, workshop, dan penguatan ICT literasi bagi guru (Atsani, 2020), serta memberikan sosialisasi kepada orangtua bahwa pentingnya kerjasama yang baik agar tidak menggantikan posisi anaknya dalam proses pembelajaran yang berlangsung melalui aplikasi yang digunakan dalam proses pembelajaran. Kerjasama antara guru dan orangtua akan memberikan dampak positif bagi perkembangan kepribadian peserta didik. Beberapa aplikasi yang dapat digunakan dalam proses pembelajaran jarak jauh yaitu: Whatsapp, Youtube, Telegram, Google classroom, Zoom, Google Meet, Google Form, Quizzis, Khoot, Laman e-learning, LMS, Video converence, Live chat, Rumah Belajar (Platform Kemdikbud), Program Guru Berbagi (Platform Kemdikbud), dan TVRI untuk daerah dengan koneksi internet yang buruk atau tanpa koneksi internet (Astini, 2020).

Disisi lain proses pembelajaran yang berlangsung dengan sistem jarak jauh, daring ataupun luring bagi peserta didik pada jenjang sekolah dasar diharapkan peserta didik dan orang tua untuk tidak memberikan tugas terus menerus. Akan lebih baik jika proses pembelajaran diisi dengan penyampaian materi oleh guru melalui video agar dapat diulang oleh peserta didik. Selain itu, pada kelas rendah proses pembelajaran jarak jauh sepenuhnya didampingi oleh orang tua, bahkan untuk pengerjaan tugas lebih di dominasi oleh orang tua atau wali dari peserta didik. Hal ini memberikan dampak negatif bagi perkembangan peserta didik dikarenakan secara tidak langsung mengajarkan peserta didik untuk tidak jujur. Padahal pendidikan dasar merupakan pondasi utama untuk menanamkan nilai-nilai karakter seperti kejujuran agar mereka tumbuh dengan akar karakter yang kuat.

Dukungan dan pendampingan orang tua dalam pembelajaran jarak jauh ataupun dari diharapkan guru agar tidak mengambil alih kegiatan pembelajaran dan tugas serta latihan yang diberikan guru. Biarkan peserta didik memiliki tanggung jawab terhadap pekerjaannya, orang tua hanya berperan untuk mengontrol pekerjaan anaknya selama 
Kukuh, Rian, Bagus. Empat Kata Judul Dari Depan...

proses pembelajaran daring. Efek yang mungkin saja tidak terlihat secara langsung adalah karakter dan kemampuan bersosialisasi peserta didik yang bermuara pada self regulated learning (SRL) dari proses pembelajaran daring selama masa pandemi covid19. SLR ini merupakan kemampuan peserta didik untuk mengelola belajarnya sendiri yang mengacu pada kemampuan untuk merubah perilaku seseorang (Siregar et al., 2018).

Kesenjangan digital yang begitu nyata selama masa pandemi covid-19 memberikan kita pemahaman bahwa diperlukan peningkatan kompetensi secara berkelanjutan bagi guru agar selalu memiliki pengetahuan dan keterampilan digital yang memadai sesuai dengan perubahan zaman, disisi lain juga diperlukan peningkatan sarana dan prasarana bagi daerah $3 \mathrm{~T}$ yang masih kesulitan mengakses internet karena belum meratanya pembangunan di wilayan Indonesia yang luas ini. Salah satu cara yang dapat diberikan untuk mengurangi kesenjangan digital adalah dengan melaksanakan pendidikan berbasis kearifan lokal (Insyiroh et al., 2020)sebagai solusi untuk menghadapi kesenjangan digital dalam kebijakan pemebalajaran jarak jauh dan dalam jaringan pada masa pandemi di Indonesia.

\section{SIMPULAN}

Realita tranformasi teknologi pendidikan di Indonesia memberikan peran yang begitu penting sehingga mengharuskan guru dan peserta didik memiliki ICT Literacy yang mumpuni untuk dapat menerapkan proses pembelajaran jarak jauh yang sesuai dengan harapan. Banyak kendala yang ditemukan dalam proses pembelajaran selama daring terutama pada pembentukan karakter peserta didik yang tidak dapat digantikan oleh teknologi. Pola pendidikan dengan tatap muka dan memiliki rentang waktu tertentu akan tetap diperlukan untuk membentuk karakter disamping keterampilan penggunaan ICT bagi peserta didik.

\section{DAFTAR RUJUKAN}

Adisel, Gawdy, A. P. (2020). Penggunaan Teknologi Informasi dan Komunikasi dalam Sistem Manajemen Pembelajaran pada masa Pandemi Covid 19. ALIGNMENT: Journal of Administration and Educational Management, 3(1), 1-10. https://journal.ipm2kpe.or.id/index.php/ALIGNMENT/article/view/1291

Astini, N. K. S. (2020). Pemanfaatan teknologi informasi dalam pembelajaran tingkat 
Kukuh, Rian, Bagus. Empat Kata Judul Dari Depan... sekolah dasar pada masa pandemi covid-19. Jurnal Lembaga Penjaminan Mutu STKIP Agama Hindu Amlapura, 11(2), 13-25.

Atsani, L. G. M. Z. (2020). Transformasi Media Pembelajaran Pada Masa Pandemi Covid-19. Al Hikmah: Jurnal Studi Islam, 1(1), 82-93. http://journal.unj.ac.id/unj/index.php/jtp

Carrillo, C., \& Flores, M. A. (2020). COVID-19 and teacher education: a literature review of online teaching and learning practices. European Journal of Teacher Education, 43(4), 466-487. https://doi.org/10.1080/02619768.2020.1821184

Dewi, W. A. F. (2020). Dampak COVID-19 terhadap Implementasi Pembelajaran Daring di Sekolah Dasar. Edukatif: Jurnal Ilmu Pendidikan, 2(1), 55-61. https://doi.org/10.31004/edukatif.v2i1.89

Donitsa-Schmidt, S., \& Ramot, R. (2020). Opportunities and challenges: teacher education in Israel in the Covid-19 pandemic. Journal of Education for Teaching, 00(00), 1-10. https://doi.org/10.1080/02607476.2020.1799708

Gumelar, D. R., \& Dinnur, S. S. (2020). Digitalisasi Pendidikan Hukum dan Prospeknya Pasca Pandemi Covid-19. Al Ahwal Al Syakhsiyyah, 1(2), 111-122.

Insyiroh, I. M., Hariani, E. P., \& Mubaroq, S. (2020). Pendidikan berbasis kearifan lokal sebagai solusi menghadapi kesenjangan digital dalam kebijakan pembelajaran jarak jauh pada masa pandemi di Indonesia. Indonesian Journal of Social Development, 1(1), 51-72.

König, J., Jäger-Biela, D. J., \& Glutsch, N. (2020). Adapting to online teaching during COVID-19 school closure: teacher education and teacher competence effects among early career teachers in Germany. European Journal of Teacher Education, 43(4), 608-622. https://doi.org/10.1080/02619768.2020.1809650

Mansyur, A. R. (2020). Dampak COVID-19 Terhadap Dinamika Pembelajaran Di Indonesia. Education and Learning Journal, 1(2), 113. https://doi.org/10.33096/eljour.v1i2.55

Nahdi, D. S., \& Jatisunda, M. G. (2020). Analisis Literasi Digital Calon Guru Sd Dalam Pembelajaran Berbasis Virtual Classroom Di Masa Pandemi Covid-19. Jurnal Cakrawala Pendas, 6(2), 116-123. https://doi.org/10.31949/jcp.v6i2.2133

Pujilestari, Y. (2020). Dampak Positif Pembelajaran Online Dalam Sistem Pendidikan Indonesia Pasca Pandemi Covid-19. Adalah, 4(1), 49-56. http://journal.uinjkt.ac.id/index.php/adalah/article/view/15394/7199

Putra, M. T. F., Arianti, \& Elbadiansyah. (2019). Analisis Penerapan Model Dan Metode Pembelajaran Tepat. Sebatik, 23, 317-323.

Putro, S. T., Widyastuti, M., \& Hastuti. (2020). Problematika pembelajaran di era pandemi covid-19 studi kasus: Indonesia, Filifina, Nigeria, Ethiopia, Finlandia, dan Jerman. 18(2), 50-64.

Rigianti, H. A. (2020). KENDALA PEMBELAJARAN DARING GURU SEKOLAH DASAR DI KABUPATEN BANJARNEGARA. Elementary School, 7(2), 297301. https://doi.org/10.1155/2010/706872

Siregar, Y. E. Y., Zulela, M., W, P. A., Rachmadtullah, R., \& Pohan, N. (2018). Self Regulation, Emotional Intelligence With Character Building In Elementary School. 251(Acec), 315-318. https://doi.org/10.2991/acec-18.2018.72

Suprihatiningsih, S., \& Sudibyo, N. A. (2020). Pelatihan Penggunaan E-Book Matematika Berbasis Terbimbing Pada Siswa SMP Daerah 3T. 3(2), 366-371.

Syibromilisi. (2020). STRATEGI BELAJAR SIEQ MELALUI HOME VISIT DI MASA 
Kukuh, Rian, Bagus. Empat Kata Judul Dari Depan...

PANDEMI COVID-19 ( CORONA VIRUS DEASES ). 4(2).

Tesi Muskania, R., \& Wilujeng, I. (2017). Pengembangan Perangkat Pembelajaran Project-Based Learning Untuk Membekali Foundational Knowledge Dan Meningkatkanscientificliteracy. Jurnal Cakrawala Pendidikan, 36(1), 34-43. https://doi.org/10.21831/cp.v36i1.8830

Widakdo, J., \& Fananie, K. G. B. (2020). Dampak Positif Pembelajaran Online Dalam Sistem Pendidikan Indonesia Pasca Pandemi Covid-19. In Perhimpunan Pelajar Indonesia $\mathrm{Se}$ -

(Vol.

4, Issue

1). http://journal.uinjkt.ac.id/index.php/adalah/article/view/15394/7199 